\section{WOMEN'S AND GIRLS' RIGHIS}

\section{0}

Supporting women and girls to enjoy the same rights as other members of the population. This includes, but is not limited to, the rights to bodily integrity and autonomy, to own property, to participate in political decision making, to equal pay for equal work, to equal quality and access to education, and to freedom from all forms of violence.

\section{OVERVIEW}

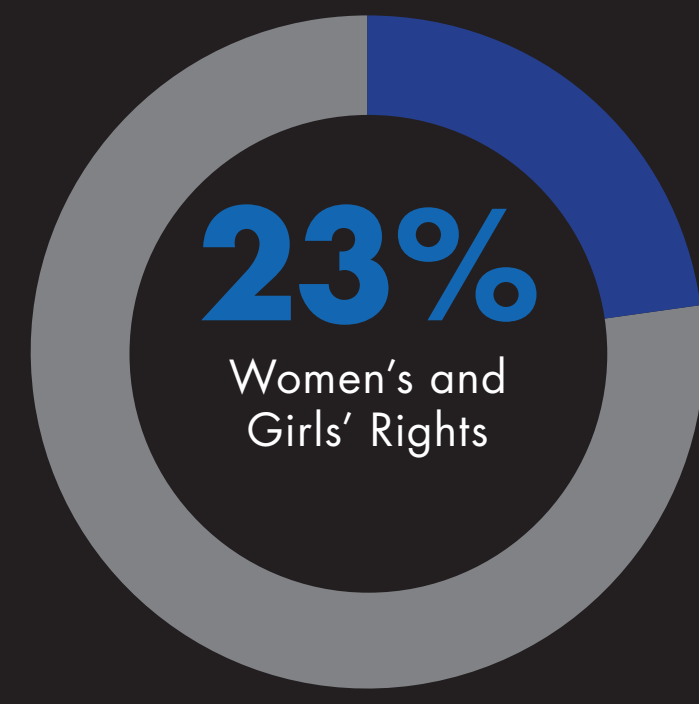

Share of overall human rights funding

$\$ 276.5$ Million out of $\$ 1.2$ Billion for all rights

\section{Of this $\mathbf{2 3} \%$}

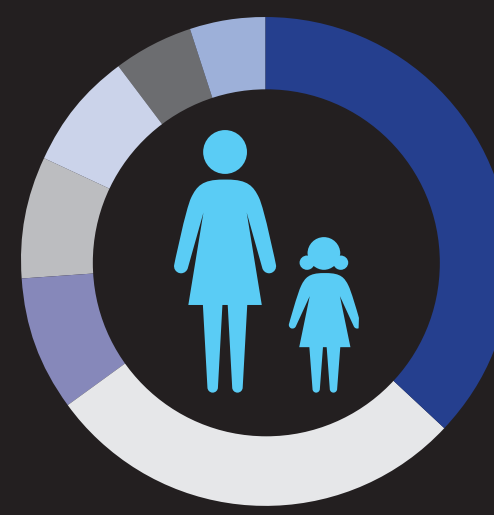

$37 \%$ Sexual and Reproductive Rights

$\mathbf{2 8} \%$ Individual Integrity, Liberty, and Security

$9 \%$ Freedom from Violence

$\mathbf{8 \%}$ Human Rights-General

$\mathbf{8 \%}$ Other Rights'

$5 \%$ Labor Rights

$5 \%$ Health and Well-being Rights

\section{RECIONAL FOCUS'2}

$50 \%$

$40 \%$

$30 \%$

$10 \%$

$0 \%$

North
America

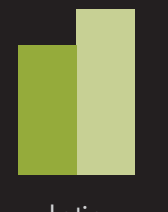

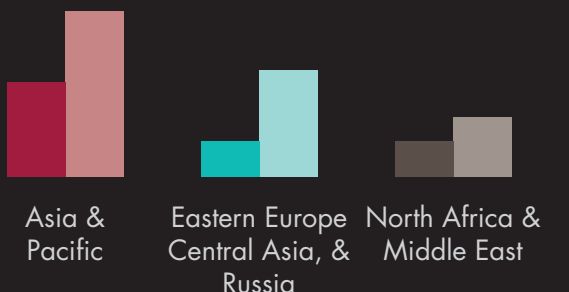

Western
Europe

\section{TOP FUNDERS}

1 Ford Foundation.

2 Susan Thompson Buffett Founda..........

$\$ 42.3$ MILLION (M)

2 Susan Thompson Buft

$\$ 40.9 \mathrm{M}$

Huber Foundation.

Open Society Foundation

(7) Sigrid Rausing Trust................................ \$8.0 M

8 Bill \& Melinda Gates Foundation...................... \$7.7 M

9 Global Fund for Women............................ \$7.7 M

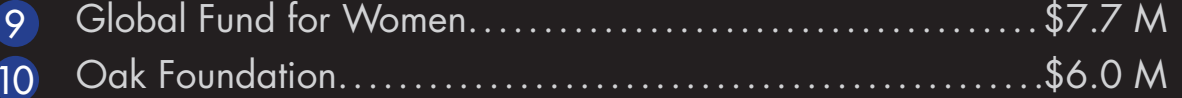

11 American Jewish World Service........................ \$5.7 M

12 W.K. Kellogg Foundation........................... \$5.4 M

13 United Nations Foundation............................. \$5.3 M

14 American Jewish World Service-Donor Advised Fund...... \$5.3 M

15 David and Lucile Packard Foundation................... \$4.4 M

16 Mama Cash ...................................... \$4.1 M

17 John D. and Catherine T. MacArthur Foundation..........\$4.0 M

18 Bloomberg Family Foundation. ............ \$3.

19 William and Flora Hewlett Foundation.................. \$3.7 M

20 ExxonMobil Foundation............................. \$3.4 M

\section{Highest Number
of Grants 591}

6 NoVo Foundation............................... \$8.5 M 


\section{ASIA \& PACIFIC}

62 FOUNDATIONS (曲 $=5)$

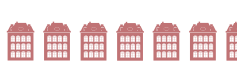

GRANT DOLLARS (回=500T) 回国国国国国国国国

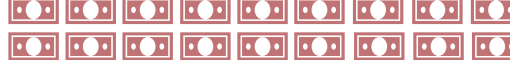

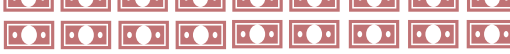
国问四

\section{TOP FUNDERS FOR THE REGION}

ISSUE FOCUS

(1) Ford Foundation ................. $\$ 5.4 \mathrm{M}$
(2) Sigrid Rausing Trust.................. $\$ 2.5 \mathrm{M}$
(3) Global Fund for Women .............. $\$ 1.5 \mathrm{M}$
(4) David and Lucile Packard Foundation. $\$ 1.4 \mathrm{M}$
(5) American Jewish World Service........ $\$ 1.3 \mathrm{M}$

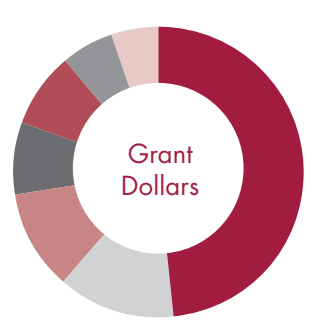

\section{SAMPLE GRANTS}

American Jewish World Service gave to Worker's Information Center in Cambodia to empower female garment workers by providing them a safe space to information and resources.

David and Lucile Packard Foundation gave to Lahore University of Management Sciences in Pakistan to launch a national women's leadership network to advocate for family planning and reproductive health and to mobilize policy changes in the corporate social responsibility agenda.

\section{CARIBBEAN}

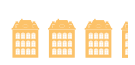

ง.,7m)

DOLLARS (圆=500T, 回国国国

\section{ISSUE FOCUS}

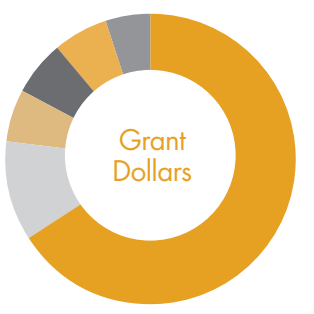

\section{TOP FUNDERS FOR THE REGION}

(1) American Jewish World

2 American Jewish World Service-

Donor Advised Fund.

(4) Lambi Fund of Haiti .....

5 Mama Cash.
16 FOUNDATIONS (- $=5$ )

334 RECIPIENTS (숌 $=10$ )

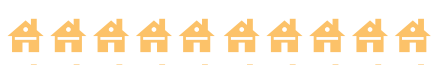

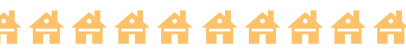

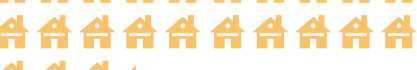

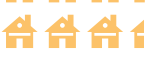

\section{$\$ 972$}

$\$ 240$ T

$\$ 105$ T

$\$ 53 \mathrm{~T}$

Individual Integrity, Liberty, and Security $66 \%$
Health and Well.bengng Rights $11 \%$
Reproductive Rights $6 \%$
Freedom from Violence $6 \%$
Human Rights-General $6 \%$

Other Rights $5 \%$

\section{SAMPLE GRANTS}

American Jewish World Service gave to Movimiento de Mujeres Dominico Haitiana in the Dominican Republic to strengthen community participation in rebuilding after the earthquake through leadership training for women and youth and workshops on economic solidarity initiatives, sexual and reproductive health and rights, civic and political participation, and disaster miligation.

Global Fund for Women gave to Alas de Mariposa in Costa Rica to take the production of The Labyrinth of the Butterflies to Honduras and Haiti as part of the women's solidarity campaign in Latin America

EASTERN EUROPE, CENTRAL ASIA, \& RUSSIA
404 RECIPIENTS (순 $=10$ )

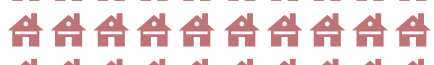

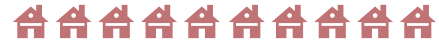

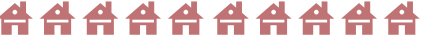
A

Indivadual hilegrity, Liberty, and Security $48 \%$

Human Rights-General $13 \%$

Sexual and Reproductive Rights $11 \%$

Freedom from Violence $8 \%$

Other Rights $8 \%$

Labor Rights $6 \%$

Access to ustice/Eguadiy Before the Low $5 \%$

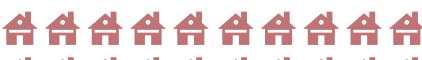

\section{FOUNDATIONS (部=5) 湅䚀湅}

Human Rights-General 6

SAMPLE GRANTS

\section{TOP FUNDERS FOR THE REGION}

(1) Susan Thompson Buffett

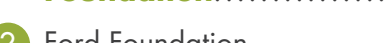

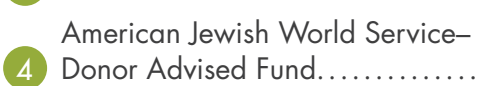

(4) Donor Advised Fund

(5) Global Fund for Women
$9.2 \mathrm{M}$ GRANT DOLLARS (回=500T)

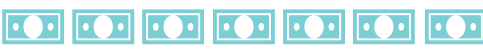

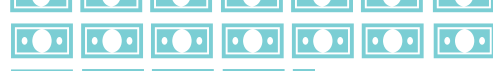
回回回回區

ISSUE FOCUS

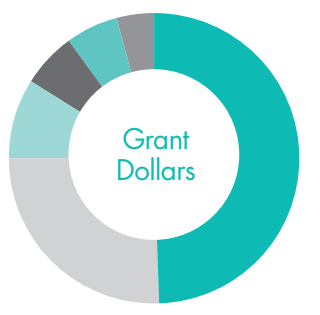

250 RECIPIENTS (告=10)

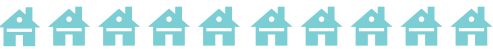

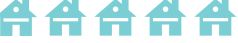

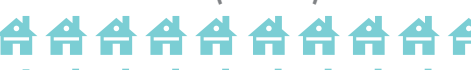

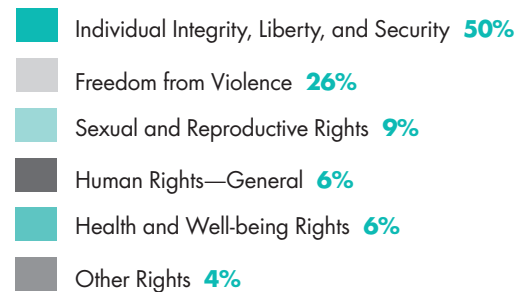

dividual Integrity Liberty and Security 50\%

Other Rights $4 \%$
Global Fund for Women gave to Motrat Qiriazi, Rural Women Activists in Kosovo for the production of a documentary film that tells the story of women (a) Unent Action Fund gave to Szuleteshaz Kozhas

\section{LATIN AMERICA \& MEXICO}

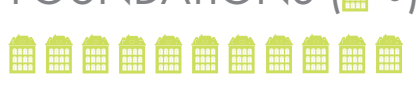

411 RECIPIENTS (告=10)

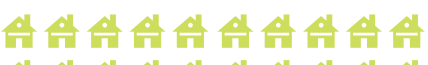

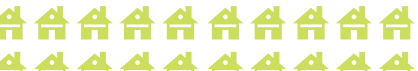

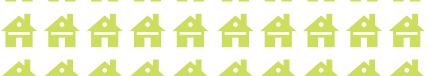

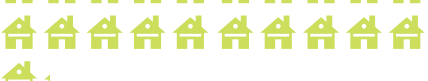$$
\text { 告 }
$$

ISSUE FOCUS

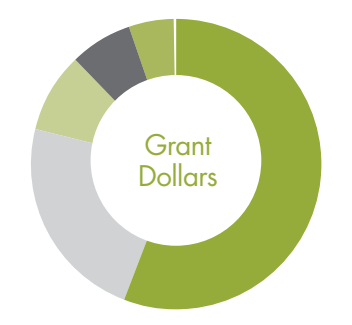

Sexual and Reproductive Rights $56 \%$

Ther Rights $9 \%$

Human Rights-General $7 \%$

\section{SAMPLE GRANTS}

Brazil Human Rights Fund gave to Association of Women Rural Workers of Lake Junco and Lake Rodrigues in Brazil to strengthen political organizations of nut breakers and provide community leadership training on issues related to gender, racial, and ethnic equity.

NIKE Foundation gave to EngenderHealth in the USA to transform an informal network of young indigenous Guatemalan female leaders into a permanent indigenous Guatemalan girl-led organization and to support the expansion of local, sustainable, indigenous girl-led networks. 


\section{NORTH AFRICA \& MIDDLE EAST}

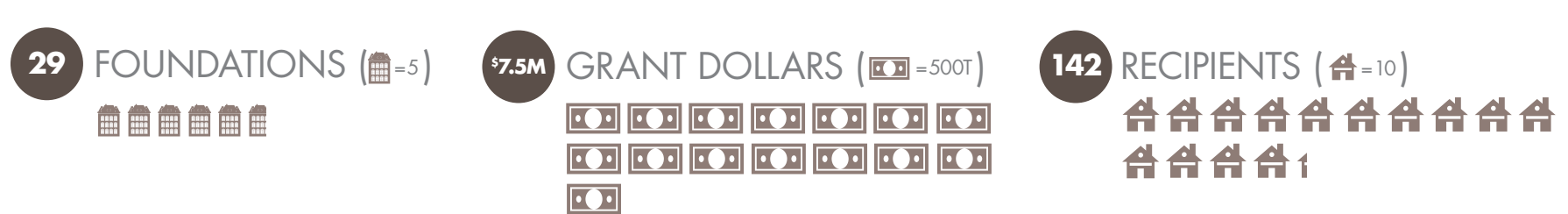

TOP FUNDERS FOR THE REGION

(1) Open Society Foundations .......\$1.6 M
2 Ford Foundation...................... $\$ 1.1 \mathrm{M}$
(3) Opus Prize Foundation.............. $\$ 1.0 \mathrm{M}$
(4) Global Fund for Women .............. $\$ 980 \mathrm{~T}$
(5) Sigrid Rausing Trust................. $\$ 634 \mathrm{~T}$
$\mathrm{M}=$ Million and T $\mathrm{T}$ Thousand

ISSUE FOCUS

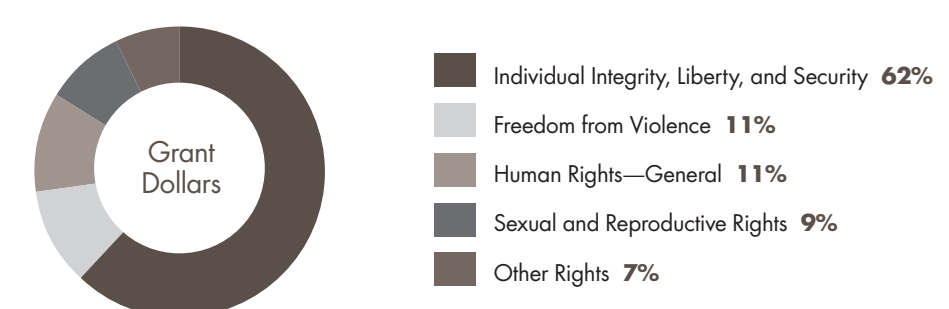

\section{SAMPLE GRANTS}

Arab Human Rights Fund gave to Bahrain Women Association in Bahrain to promote women's social status and eradicate discrimination against women via legal reforms on the issue of citizenship, based on the Convention on the Elimination of All Forms of Discrimination against Women.

U.S. Institute of Peace gave to City of Mosul in Iraq to enhance local capacily to increaser rural and marginalized women's awareness of rights through establishing o mobile clinic and telephone hotline, providing training in women's rights, publishing materials on women's rights, engaging in TV and radio advocaccy, and launching a web site that provides info

\section{NORTH AMERICA}

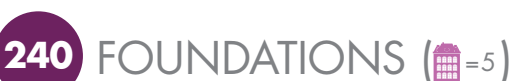

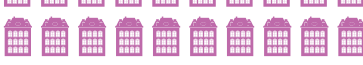

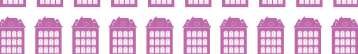

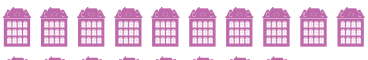

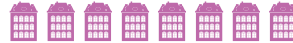

\section{TOP FUNDERS FOR THE REGION}

$\$ 30.9 \mathrm{M}$

2 Huber Foundation. $\$ 14.0 \mathrm{M}$

3 Ford Foundation....

(5) Allstate $\$ 13.4 \mathrm{M}$

$\$ 8.0 \mathrm{M}$

$\$ 3.4 \mathrm{M}$

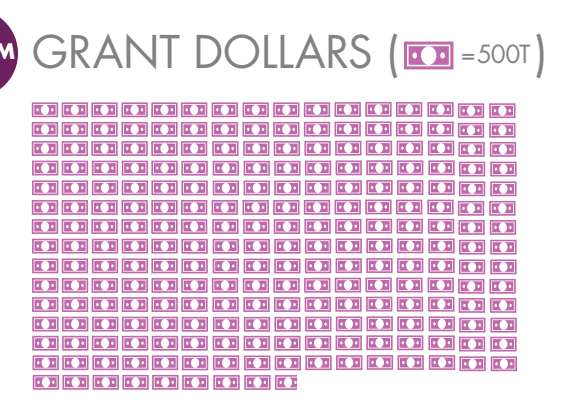

489 RECIPIENTS (숑=10)

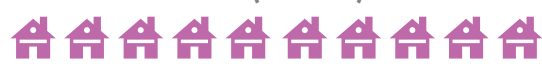

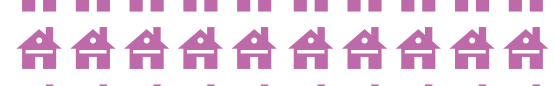

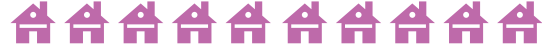

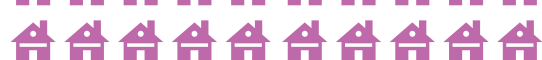

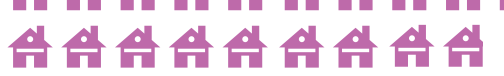

\section{SAMPLE GRANTS}

Moriah Fund gave to Christian Community in the USA tor work at the intersection of sexuality and religion to advance sexual health, sexuality education, and sexual and reproductive justice in America's faith communities and society at large.

General Service Foundation gave to National Health Law Program in the USA to increase reproductive health access for low-income women and women of color by advancing their legal rights to publicly financed health care, using both grasssoots legal assistance and policy advocacy to target specific barriers to care.
ISSUE FOCUS

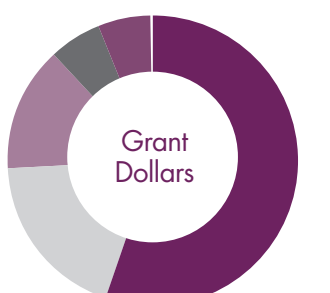
Individual Integrity, Liberty, and Security $19 \%$ Civic and Political Parricipation $6 \%$ Labor Rights $6 \%$

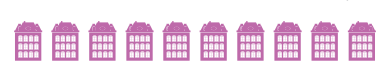

\section{(1) Susan Thompson Buffett}

(4) Vanguard Charitable Endowment

\section{SUB-SAHARAN AFRICA}

71 FOUNDATIONS (쀼)

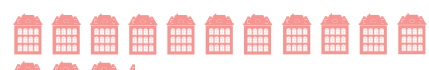
细䚀

TOP FUNDERS FOR THE REGION

(1) Ford Foundation..................... $\$ 8.6 \mathrm{M}$
(2) American Jewish World Service-
Donor Advised Fund..................... $\$ 4.0 \mathrm{M}$
(3) Sigrid Rausing Trust.................. $\$ 2.8 \mathrm{M}$
(4) American Jewish World Service........ $\$ 2.3 \mathrm{M}$
5 African Women's Development Fund. $\$ 2.0 \mathrm{M}$

SAMPLE GRANTS

Global Fund for Women gave to ABANTU for Development in Ghana to organize the West Africa workshop on Women's Activism in Post-Conflict Contexts in Accra by developing research design and oction plans; trining lead researchers; establishing research networks and developing agendas for policy activism and improved capacity for anti-militarism work.

New Field Foundation gave to Women Organizing for Change in Agriculture and Natural Resource Management in the USA for building rural women's leadership capacity in farmer organizations in Cameroon for better access to benefits from Reducing Emissions from Deforestation and Forest Degradation

\section{WESTERN EUROPE}

28 FOUNDATIONS (- $=5)$

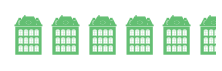

Sexual and Reproductive Rights $56 \%$ Other Rights $14 \%$

\subsection{M}

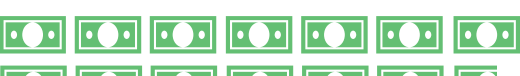
回回回回回回
68 RECIPIENTS (숑=10)

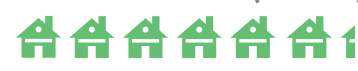

TOP FUNDERS FOR THE REGION

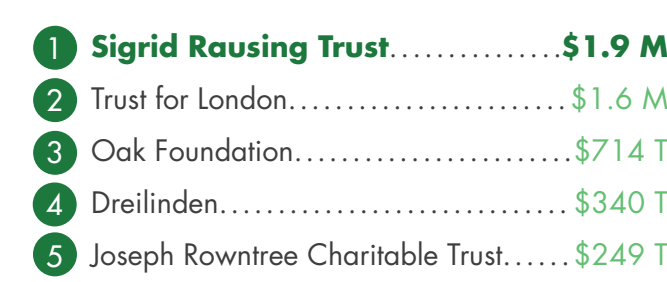

(5) Joseph Rowntree Charitable Trust....... $\$ 249$ T

$$
M=\text { Million and } T=\text { Thousand }
$$

\section{SAMPLE GRANTS}

Northern Rock Foundation gave to Open Clasp Theatre Company in the United Kingdom for "Herstory Told," which raises awareness of sex work, sexual exploitation, and women in the criminal justice system.

Bill \& Melinda Gates Foundation gave to the European Parliamentary Forum on Population and Development in the United Kingdom to enable women seeking asylum in the United Kingdom to obtain protection and security, maintain their dignity, and be treated with respect during the asylum process.
Individual Integrity, liberty, and Security $46 \%$ Freedom from Violence $19 \%$ Labor Rights $11 \%$ Human Rights-General 6\% Sexual and Reproductive Rights Sexual and Reprod 